\title{
The Effect of Therapeutic Plasma Exchange on COVID-19 Therapy
}

\section{Terapötik Plazma Değişiminin COVID-19 Tedavisine Etkisi}

\author{
(D) Cansu GÖNCÜOĞLU*, (D) Fatma Nisa BALLI, (D) Aygin BAYRAKTAR EKINCIOĞLU \\ Hacettepe University Faculty of Pharmacy, Department of Clinical Pharmacy, Ankara, Turkey
}

Key words: COVID-19 treatment, therapeutic plasma exchange, drug removal, pharmacokinetic

Anahtar Kelimeler: COVID-19 tedavisi, terapötik plazma değişimi, ilaç itrahı, farmakokinetik

\section{Dear Editor,}

The global pandemic caused by the Severe Acute Respiratory syndromeCoronavirus-2 started in Wuhan, China, in December 2019 and spread throughout the world. It is known that cytokine storms play an important role in acute respiratory distress syndrome and multiorgan dysfunction, which are among the main causes of mortality in Coronavirus Disease-2019 (COVID-19) patients. A cytokine storm is triggered by the secretion of proinflammatory cytokines such as tumor necrosis factor- $\alpha$; interleukin (IL)-1b, IL-2, IL-6, IL-8, and IL-10; and interferon- $\gamma$. An excessive inflammatory response occurs as a result of this triggering, which leads to life-threatening clinical symptoms.' It has been shown that therapeutic plasma exchange (TPE) may be effective in suppressing cytokine storms. ${ }^{2}$

The main parameters in evaluating the effect of TPE on drug therapy are the volume of distribution and the affinity of drugs binding to plasma proteins. Drugs with low volumes of distribution $(<0.2 \mathrm{~L} / \mathrm{kg})$ and high plasma protein binding $(>80 \%)$ often remain in the intravascular compartment and are likely to be affected by TPE. However, not only those two parameters affect the processes of drug removal by TPE; the half-life $(>2 \mathrm{~h})$, endogenous drug clearance ( $(4 \mathrm{~mL} / \mathrm{min})$, hydrophilic/lipophilic properties of the drug, and the time between the onset of TPE and drug intake may also affect the rate of excretion. Drugs with a half-life longer than $2 \mathrm{~h}$ and that are slowly metabolized or have a low clearance rate are more likely to be excreted by TPE. ${ }^{3}$

TPE has been shown to increase interferon clearance in patients with hepatitis C-related vasculitis. ${ }^{4}$ No studies on the effects of TPE on other drugs used in the treatment of COVID-19 have been found. The pharmacokinetic properties of the drugs used to treat COVID-19 are shown in Table 1. Accordingly, interferon, intravenous immunoglobulin, and lopinavir/ritonavir are likely to be affected by TPE. There are not enough data on favipiravir, oseltamivir, tocilizumab, and remdesivir to allow them to be evaluated; however, considering their low distribution volumes and long half-lives, it can be assumed that they are also removed by TPE. In cases when the drug is likely to be excreted with TPE, it is recommended to change the drug administration time to a time after TPE in order not to disrupt the regular blood concentration of the drug. Thus, with rational drug use, the blood level of the drug may be prevented from being affected by TPE and the patient obtains the maximum effect expected from the drug. Blood levels of drugs should be monitored if possible. Clinicians should always consider and evaluate the pharmacokinetic profiles of drugs when opting for co-administration with other therapeutic options. 
Table 1. Pharmacokinetic characteristics of drugs that are used to treat COVID-19

\begin{tabular}{lllll} 
Drug & Volume of distribution & Plasma protein binding & Half-life & References \\
\hline Hydroxychloroquine & $47.257 \mathrm{~L}$ & $40 \%$ & $45 \pm 15$ days & 5 \\
\hline Chloroquine & $65.000 \mathrm{~L}$ & $55 \%$ & $41 \pm 11$ days & 5 \\
\hline Azithromycin & $31 \mathrm{~L} / \mathrm{kg}$ & $7-51 \%$ & $68-72$ hours & 6 \\
\hline Ribavirin & $2825 \mathrm{~L}$ & None & $24-298$ hours & 6 \\
\hline Umifenovir & Data not available & Data not available & $17-21$ hours & 7 \\
\hline Methylprednisolone & $1.38 \mathrm{~L} / \mathrm{kg}$ & $78 \%$ & 2.3 hours & 8 \\
\hline Oseltamivir & $23-26 \mathrm{~L}$ & $3-42 \%$ & $1-10$ hours & 6 \\
\hline Tocilizumab & $6.4 \mathrm{~L}$ & Data not available & $11-13$ days & 6 \\
\hline Favipiravir & $15-20 \mathrm{~L}$ & $54 \%$ & $2-5.5$ hours & 9 \\
\hline Remdesivir & Data not available & Data not available & 69 minutes & 10 \\
\hline Ritonavir & $0.41 \pm 0.25 \mathrm{~L} / \mathrm{kg}$ & $98-99 \%$ & $3-5$ hours & 6 \\
\hline Lopinavir & Data not available & $98-99 \%$ & $5-6$ hours & 6 \\
\hline IVIG & $0.05 \pm 0.13 \mathrm{~L} / \mathrm{kg}$ & Data not available & $14-24$ days & 6 \\
\hline
\end{tabular}

Not expected to be affected by TPE Suspected to be affected by TPE Likely to be affected by TPE, TPE: Therapeutic plasma exchange

Conflicts of interest: No conflict of interest was declared by the authors. The authors alone are responsible for the content and writing of the paper.

\section{REFERENCES}

1. Liu B, Li M, Zhou Z, Guan X, Xiang Y. Can we use interleukin-6 (IL6) blockade for coronavirus disease 2019 (COVID-19)-induced cytokine release syndrome (CRS)? J Autoimmun. 2020;111:102452.

2. Choi S, Kim MC, Kwon JS, Kim JY, Lee KH, Kim SH. Case Report: use of plasma exchange followed by convalescent plasma therapy in a critically ill patient with severe fever and thrombocytopenia syndrome-associated encephalopathy: cytokine/chemokine concentrations, viral loads, and antibody responses. Am J Trop Med Hyg. 2018;99:1466-1468.

3. Cheng CW, Hendrickson JE, Tormey CA, Sidhu D. Therapeutic Plasma Exchange and Its Impact on Drug Levels: An ACLPS Critical Review. Am J Clin Pathol. 2017;148:190-198.

4. Hausfater P, Cacoub P, Assogba U, Lebon P, Piette JC. Plasma exchange and interferon-alpha pharmacokinetics in patients with hepatitis $C$ virusassociated systemic vasculitis. Nephron. 2002;91:627-630.
5. Schrezenmeier E, Dorner T. Mechanisms of action of hydroxychloroquine and chloroquine: implications for rheumatology. Nat Rev Rheumatol. 2020;16:155-166.

6. Wolters Kluwer UpToDate ${ }^{\circledR}$. Last accessed date: 20.08.2020. Accessed 20/08/2020. Available from: https://www.uptodate.com/

7. Deng P, Zhong D, Yu K, Zhang Y, Wang T, Chen X. Pharmacokinetics, metabolism, and excretion of the antiviral drug arbidol in humans. Antimicrob Agents Chemother. 2013;57:1743-1755.

8. Szefler SJ, Ebling WF, Georgitis JW, Jusko WJ. Methylprednisolone versus prednisolone pharmacokinetics in relation to dose in adults. Eur J Clin Pharmacol. 1986;30:323-329.

9. Nguyen TH, Guedj J, Anglaret X, Laouenan C, Madelain V, Taburet AM, Baize S, Sissoko D, Pastorino B, Rodallec A, Piorkowski G, Carazo S, Conde MN, Gala JL, Bore JA, Carbonnelle C, Jacquot F, Raoul $H$, Malvy D, de Lamballerie X, Mentre F, JIKI study group. Favipiravir pharmacokinetics in Ebola-Infected patients of the JIKI trial reveals concentrations lower than targeted. Plos Negl Trop Dis. 017;11:e0005389.

10. Agency EM (2020) Summary on compassionate use: Remdesivir Gilead https://www.ema.europa.eu/en/documents/other/summarycompassionate-use-remdesivir-gilead_en.pdf 